\title{
Efficiency of Silver Ion-Silica Solid Phase Extraction for Elimination of Sulfur Compounds during Pesticide Multiresidue Analysis in Allium Species
}

\author{
Jin-Woo Park, Kyung-Mi Moon', Young-Whan Choi ${ }^{2}$ and Young-Guen Lee ${ }^{3}$ \\ Incheon Public Procurement Service, Incheon, \\ ${ }^{1}$ National Agricultural Products Quality Management Service Gyungnam provincial Office, Changwon, Department of ${ }^{2}$ Horticultural Bioscience, \\ ${ }^{3}$ Department of Food Science and Technology, College of Natural Resources and Life Science, Pusan National University
}

Received October 12, 2009 /Accepted December 3, 2009

\begin{abstract}
Since organic sulfur compounds respond to GC/ECD sensitively, they interfere with quantitative separation of pesticides during residual pesticide analysis of Allium species. In this study, it was intended to develop a rapid and simple method for pesticide multi-residues analysis through clean-up and interferences by a solid-phase extraction (SPE). An SPE method employing silver nitrate impregnated Florosil cartridge was developed and evaluated for the elimination of sulfur compounds from the test solution of Allium species during pesticide residues analysis. The silver nitrate impregnated Florosil cartridge was prepared by efflux of $3 \mathrm{ml}$ of $20 \%$ silver nitrate solution through Florosil cartridge $(1$ $\mathrm{g}$ packing, $6 \mathrm{ml}$ tube). The extracts equivalent to 2,46 , and $10 \mathrm{~g}$ of each sample were loaded onto the cartridge and allowed to exude, and then the exudations were analyzed by GC/ECD. More than $95 \%$ of sulfur compounds were removed from the loaded extracts equivalent, up to $6 \mathrm{~g}$ in onion, 4 $\mathrm{g}$ in spring onion and $4 \mathrm{~g}$ in shallot, respectively. 40 pesticides were spiked in the Allium species and loaded onto the cartridge to determine the recoveries; from this, the recoveries of 34 pesticides were within $70 \sim 120 \%$.
\end{abstract}

Key words : Florosil cartridge, pesticide residue, silver nitrate impregnated Allium species, solidphase extraction, sulfur compounds

\section{서 론}

농작물의 재배 중 사용한 농약은 최종적으로 생산된 농산물 또는 가공식품에 잔류되어 인체에 위해를 줄 수 있으며, 이에 대한 소비자들의 우려 및 관심에 따른 정부의 잔류량 규제 및 학계의 지속적인 관심에 의하여 잔류농약 분석에 관한 공 정분석법들이 갖추어져 왔다 $[1,8,26]$. 잔류농약의 공정분석법 으로서는, 목표농약성분의 극성, 비점 및 내열성 등에 따라서 gas chromatography (GC), liquid chromatography (LC), capillary electrophoresis (CE), liquid chromatography-mass spectrometry (LC/MS) 및 gas chromatography-mass spectrometry $(\mathrm{GC} / \mathrm{MS})$ 등의 기기학적 기술들이 적용되어 왔다 $[5,6,10,11,13,22,24]$. 그러나, 농약이 함유 또는 부착된 매체인 농산물 또는 식품성분의 복잡성 그리고 잔류농약의 희박한 농도로 인하여, 기기분석 이전에 목표농약의 정제 및 농축을 위하여 매체성분 및 농약의 특성을 고려한 전처리가 필수적이 다[1,6,7,26]. 이러한 전처리방법으로서 용매-용매추출법(liquidliquid extraction) [7]이 널리 사용되고 있었으나, 근래 FDA와 KFDA에서 공정법으로 채택하고 있는 solid-phase extraction cartridge [5,11,20], 캐나다의 Waterloo 대학에서 개발한 solid-

*Corresponding author

Tel : +82-55-350-5522, Fax : +82-55-350-5529

E-mail : ywchoi@pusan.ac.kr phase micro extraction [23], 그밖에 matrix solid-phase dispersion $[14,23]$ 및 gel permeation chromatographic clean-up [2], accelerated solvent extraction [12,25] 등 다양한 전처리법 이 개발되었으며, 기존의 용매-용매추출법에 비해 간편하고 신속하면서 용매 소비량이 적은 장점 때문에 최근 잔류농약분 석에서 널리 이용되고 있는 추세이다[5,11,12,14,20,23,27]. 한 편, 양파, 대파 및 쪽파 등의 파속류 작물의 세포질에는 alliin 또는 isoalliin 등의 황화합물이 다량 함유되어 있고 가공 또는 잔류농약 분석을 위하여 이들 작물의 기계적 파쇄시 액포에 있던 allinase의 효소작용에 의하여 allicin 등의 thiosulfinates 로 전환된다고[4,16,18,29] 알려져 있다. 그리고 thiosulfinates 는 화학적으로 매우 불안정하여 분자내 재배열에 의하여, allyl disulfide, diallyl sulfide, diallyl disulfide, dimethyl sulfide, 2-vinyl-2,4-dihydro-1,3-dithiin, 3-vinyl-3,4-dihydro-1,2-dithiin, ajoene 등의 다양한 황화합물들을 생성시킨다[15]. 또한 이 황 화합물들의 C-S결합과 농약성분들의 C-C결합의 극성 차이가 적어서[17] Allium속 작물들의 기기분석에서 peak들이 중첩 되거나 근접하여 분석에 방해가 되고 있지만 아직까지 적절한 정제방법이 없는 실정이다. 따라서 파속류 작물들의 잔류농약 분석에서 방해성분인 황화합물들을 제거시키고자 기존의 solid-phase extraction (SPE)에 사용한 Florosil에 $\mathrm{AgNO}_{3}$ 를 처리 하여 은이온을 흡착시킨 cartridge (silver nitrate impregnated florosil cartridge)를 조제하고, 이를 이용하여 정제한 후 GC로 
분석한 결과를 비교하여, 이 정제방법의 효율성을 검토하고 각 농약들의 회수율도 측정하였다.

\section{재료 및 방법}

\section{시약 및 농약}

표준물질은 Dr. Ehrenstorfer Reference Material사 제품을 구입하여 농도별로 조제하여 사용하였고, 실험에 사용된 시약 중 acetonitrile, acetone, hexane은 Merck사 PRA급을 사용하 였으며 $\mathrm{NaCl}$ 은 삼천사 제품을 사용하였다. $\mathrm{AgNO}_{3}$ 는 Junsei chemical사 제품 $10 \mathrm{~g}$ 을 $50 \mathrm{ml}$ 증류수에 녹여 사용하였으며, Florosil cartridge ( $1 \mathrm{~g}$ packing, $6 \mathrm{ml}$ tube)는 Varian사의 제품 을 사용하였다. 본 연구에 적용한 농약은 농약 안전사용 기준 이 설정되고 $\mathrm{MRL}$ 이 고시되어 있는 농약들 중 검출빈도가 높 고 농산물중의 잔류허용기준이 설정된 농약 성분들을 선정하 여 각각 G1, G2 및 G3 3개 그룹으로 합성하였다. 그 목록은 Table 1에서 보는 바와 같다.

\section{실험 재료}

실험에 사용된 양파, 대파, 쪽파는 부산 연제구 거제시장 및 대형유통매장에서 판매되는 제품 중 친환경 무농약인증 농산물을 사용하여 시료중의 잔류농약으로 인한 분석결과의 간섭을 최소화 하였다.

\section{은이온흡착 cartridge 조제}

$\mathrm{AgNO}_{3} 10 \mathrm{~g}$ 을 $50 \mathrm{ml}$ 증류수에 녹인 $\mathrm{AgNO}_{3}$ 용액 $3 \mathrm{ml}$ 을 Varian사 Florosil cartridge ( $1 \mathrm{~g}$ packing, $6 \mathrm{ml}$ tube)에 가해 초당 2 3방울 속도로 유출하였다. 이때 Varian사의 VAC ELUT SPS 24 감압기를 이용하여 유속을 조절하였다. 이후 Florosil cartridge에 acetone $6 \mathrm{ml}$ 를 가한 후 감압장치를 이용 하여 초당 2 3방울 속도로 유출하였다.

Table 1. List of pesticide groups used for recovery test

\begin{tabular}{|c|c|}
\hline Classification & Pesticides \\
\hline $\begin{array}{c}\text { Group } 1 \\
\text { (17 species) }\end{array}$ & $\begin{array}{l}\text { Lufenuron, Trifluralin, Propanil, Alachlor, } \\
\text { Dichlofluanid, Dicofol, Pendimethalin, } \\
\text { Fipronil, Isoprothiolane, Oxadiazon, } \\
\text { Buprofezin, Chlorfenapyr, Bifenthrin, Bifenox, } \\
\text { Cyhalothrin, Fubfenprox, Deltamethrin }\end{array}$ \\
\hline $\begin{array}{c}\text { Group } 2 \\
\text { (12 species) }\end{array}$ & $\begin{array}{l}\text { Flufenoxuron, Chlorfluazuron, Folpet, } \\
\text { Oxyfluorfen, Thenylchlor, Fenpropathrin, } \\
\text { Tetradifon, Acrinathrin, Pyridaben, } \\
\text { Flucythrinate, Fenvalerate, Tralomethrin }\end{array}$ \\
\hline $\begin{array}{c}\text { Group } 3 \\
\text { (11 species) }\end{array}$ & $\begin{array}{l}\text { Ethalfluralin, Chlorothalonil, Vinclozolin, } \\
\text { Metolachlor, Tolylfluanid, Procymidone, } \\
\text { Endosulfan, Kresoxim-methyl, Iprodione, } \\
\text { Cyfluthrin, Cypermethrin }\end{array}$ \\
\hline
\end{tabular}

\section{시료의 전처리 및 정제}

본 실험에서 제조한 은이온흡착 cartridge를 이용하여 양파, 대파 및 쪽파에 함유되어 있는 황화합물의 제거 효율 및 잔류 농약의 회수율을 조사하기 위하여, 각 시료를 식품공전의 잔 류농약 시료조제방법[18]으로 전처리하였다. 즉, 시료 $50 \mathrm{~g}$ 에 acetonitrile $100 \mathrm{ml}$ 을 가하고 5,000 rpm의 homogenizer에서 3 분간 blending한 후 $\mathrm{NaCl} 6 \mathrm{~g}$ 을 넣고 shaking하였다. 그리고 $3,000 \mathrm{rpm}$ 에서 5 분간 원심분리한 상등액(acetonitrile층) $4 \mathrm{ml}$ $(2 \mathrm{~g}), 8 \mathrm{ml}(4 \mathrm{~g}), 12 \mathrm{ml}(6 \mathrm{~g})$ 및 $20 \mathrm{ml}(10 \mathrm{~g})$ 을 각각 취하여 감압 농축하였다. 정제과정은, 우선 은이온흡착 cartridge에 hexane+acetone 혼합액(20:80) $6 \mathrm{ml}$ 를 가하여 초당 2 3방울 속도로 용출시킨 후, 전처리한 농축액을 hexane+acetone 혼합 액(20:80) $2 \mathrm{ml}$ 로 2회 녹여 초당 1 2방울 속도로 용출하고 hexane+acetone 혼합액(20:80) $6 \mathrm{ml}$ 를 동일한 속도로 다시 용 출시켰다. 용출액은 질소미세농축기를 이용하여 농축하고 그 잔사를 acetone $2 \mathrm{ml}$ 에 녹여서 $\mathrm{GC} / \mathrm{ECD}$ 분석용 시험액으로 하였다.

\section{회수율}

파속류의 잔류농약분석시 유기황화합물 등의 방해물질의 제거에 이용한 은이온흡착 cartridge에서 각 농약의 회수율을 측정하기 위하여 일반 재배농가에서 많이 사용되고 있는 농약 40 종을 각각 G1, G2 및 G3 그룹으로 분류하였다. 회수율은 양파 3점, 대파 3점, 쪽파 3점에 각각의 농약을 $1 \mathrm{ppm}$ 수준으 로 혼합 조제하여 각 성분별 3 반복으로 살포한 후 이들을 시료 로 하여 전처리하고 은이온흡착 cartridge에서 정제한 후 GC/ $\mathrm{ECD}$ 로 분석하여 각 농약의 회수율을 산출하였다.

\section{$\mathrm{GC} / \mathrm{ECD}$ 에 의한 분석}

HP 8690 GC에 DB5 capillary column (i.d $0.25 \mathrm{~mm} \times$ film thickness $0.25 \mu \mathrm{m} \times 30 \mathrm{~m}$ )을 장착하여 inlet temp. $250^{\circ} \mathrm{C}$, detector temp. $320^{\circ} \mathrm{C}$, 그리고 oven은 initial temp. $80^{\circ} \mathrm{C}$ (2분 간) 에서 $15^{\circ} \mathrm{C} / \mathrm{min}$ 으로 $180^{\circ} \mathrm{C}, 4^{\circ} \mathrm{C} /$ 분으로 $250\left(4\right.$ 분 간), $10^{\circ} \mathrm{C} /$ 분 으로 $300^{\circ} \mathrm{C}$ (6분 간)로 상승시켰다.

\section{결과 및 고찰}

\section{제거효율성}

양파, 대파 및 쪽파 시료 각 $50 \mathrm{~g}$ 을 칭량 후 acetonitrile을 $100 \mathrm{ml}$ 첨가하여 추출한 용액 $4 \mathrm{ml}(2 \mathrm{~g}), 8 \mathrm{ml}(4 \mathrm{~g}), 12 \mathrm{ml}$ $(6 \mathrm{~g})$ 및 $20 \mathrm{ml}(10 \mathrm{~g})$ 을, 은이온흡착 cartridge와 기존의 Florosil cartridge에 각각 용출시키고 이 용출액을 $\mathrm{GC}$ 로써 분 석한 크로마토그램을 비교한 결과를 Fig. 1 3에 나타내었다. 양파의 경우 기존의 Florosil cartridge에 시료 $8 \mathrm{ml}(4 \mathrm{~g})$ 를 용출시킨 용액에서부터 황화합물 등 방해물질의 peak (Fig. 


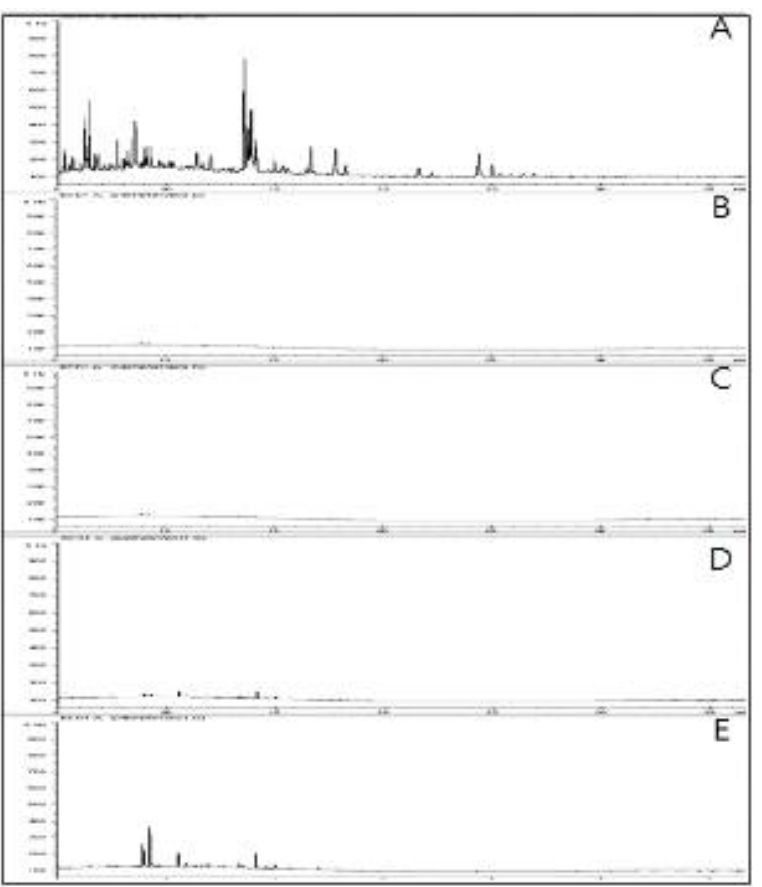

Fig. 1. Effect of silver ion impregnated Florosil cartridge on removal of sulfur compounds from onion extracts. Onion $(4 \mathrm{~g})$ extract loaded on raw Florosil cartridge $(\mathrm{A})$, and $2 \mathrm{~g}$ (B), $4 \mathrm{~g}(\mathrm{C}), 6 \mathrm{~g}$ (D) and $10 \mathrm{~g}$ (E) on silver ion impregnated Florosil cartridge, respectively.

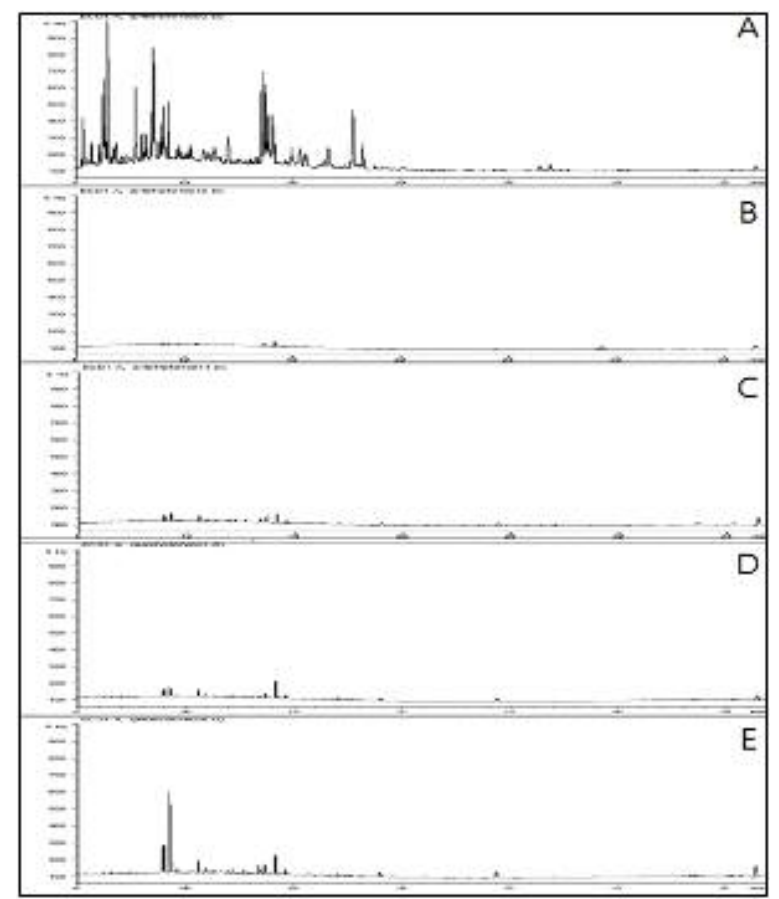

Fig. 2. Effect of silver ion impregnated Florosil cartridge on removal of sulfur compounds from spring onion extracts. Spring onion $(4 \mathrm{~g})$ extract loaded on raw Florosil cartridge (A), and $2 \mathrm{~g}(\mathrm{~B}), 4 \mathrm{~g}(\mathrm{C}), 6 \mathrm{~g}$ (D) and $10 \mathrm{~g}$ (E) on silver ion impregnated Florosil cartridge, respectively.
$1 \mathrm{~A})$ 로 인하여 잔류농약의 정량에 어려움이 나타나기 시작하 였다. 그러나 은이온흡착 cartridge에서 양파 시료 $4 \mathrm{~g}$ 을 용출 시켰을 경우 방해물질 peak는 거의 모두 제거되었으며, 시료 $6 \mathrm{~g}$ 용출시 방해물질 peak가 나타났으나 기존의 Florosil cartridge에서 용출한 시험액에 비하여 방해물질의 총 peak면적 의 $95 \%$ 이상 제거되어 잔류농약 정량에는 지장을 주지 않을 것으로 추정되었으며, 시료를 $10 \mathrm{~g}$ 으로 증가하여 용출시 방해 물질의 간섭으로 인하여 잔류농약의 정량이 어려웠다. 대파의 경우 기존의 Florosil cartridge에 시료 $4 \mathrm{~g}$ 을 용출시켰을 경우 (Fig. 2A)에는 황화합물 등의 방해물질 peak 수량 및 총면적이 양파의 경우보다 더 많이 나타났으며, 은이온흡착 cartridge를 사용하여 용출한 결과, 시료 $2 \mathrm{~g}$ 을 용출하였을 때까지는 방해 물질 peak가 전혀 보이지 않았으나, 시료 $4 \mathrm{~g}$ 용출 시 방해물질 peak가 나타나기 시작하였으며, 시료 $6 \mathrm{~g}$ 용출 시 방해물질의 간섭으로 인하여 잔류농약의 정량에 어려움이 있을 것으로 생각된다. 쪽파의 경우에는 기존의 Florosil cartridge에 시료 $4 \mathrm{~g}$ 을 용출하였을 때 황화합물 등의 방해물질 peak 양상(Fig. $3 \mathrm{~A})$ 이 대파와 비슷하였다. 쪽파의 시료에 은이온흡착 cartridge를 사용한 결과, 시료 $2 \mathrm{~g}$ 을 용출하였을 때까지는 방해물 질 peak가 보이지 않았으나, 시료 $4 \mathrm{~g}$ 용출 시 방해물질 peak 가 나타나기 시작하였으며, 시료 $6 \mathrm{~g}$ 용출 시 방해물질의 간섭 으로 인하여 잔류농약의 정량에 어려움이 있었다. 이러한 결



Fig. 3. Effect of silver ion impregnated Florosil cartridge on removal of sulfur compounds from shallot extracts. Shallot $(4 \mathrm{~g})$ extract loaded on raw Florosil cartridge (A), and $2 \mathrm{~g}(\mathrm{~B}), 4 \mathrm{~g}(\mathrm{C}), 6 \mathrm{~g}(\mathrm{D})$ and $10 \mathrm{~g}(\mathrm{E})$ on silver ion impregnated Florosil cartridge, respectively. 
과에서 양파는 $6 \mathrm{~g}$, 대파는 $4 \mathrm{~g}$, 그리고 쪽파는 $4 \mathrm{~g}$ 까지의 시료 량을 은이온흡착 cartridge을 사용하여 전처리를 할 경우 황화 합물 등의 불순물을 $95 \%$ 이상 제거할 수 있어, 파속류농산물 의 잔류농약분석에서 효율적인 전처리법으로서 활용할 수 있 다고 판단되었다. 금속의 착이온을 특정성분의 분리에 처음으 로 이용한 경우는 1975년 Vough와 Dooley [28]가 양이온교환 수지에 구리를 결합시킨 liquid chromatography로써 방향족 탄화수소에서 alkyl 및 aryl sulfides의 분리를 시도한 것이며, 이후 Gundermann 등[9]은 soloid phase에 구리, 수은, palladium 등의 금속원자와 황화합물의 착물형성을 이용하여 황화 합물의 분리를 행하였다. 또한 Bennett와 Larter[3]는 은이온 을 착이온으로 이용한 silver ion-silica solid phase extraction 을 실시하여 경유와 중유에서 지방족 및 방향족 탄화수소의 분리를 시도하였으며, Michael 등[17]은 석유로부터 황화합물 을 분리한 결과에서 주석, 은 및 palladium염이 철 및 구리보 다 효과적이라고 하였다.

\section{회수율}

각 시료의 회수율 측정에서, 대조용으로 기존 Florosil cartridge를 이용한 분석에서 황화합물 등의 방해물질과 살포한 농약성분들과의 중첩 및 인접으로 인하여 판독이 어려운 것과 은이온흡착 cartridge에서 방해물질은 제거되고 G1그룹 농약 성분들만 검출된 크로마토그램을 비교한 결과의 예를 Fig. 4 에 나타내었다. 그리고, 은이온흡착 cartridge를 이용하여 정제한 후 $\mathrm{GC} / \mathrm{ECD}$ 분석한 결과에서 산출한 각 농산물 중 농약성분 의 회수율을 농약그룹별로 Table 2, 3 및 4에 나타내었다. 먼저 Table 2에서, 양파는 17종의 G1 그룹 농약 중에서 11 성분이 $80 \%$ 이상의 회수율을 나타내었으나, dicofol은 74.9 , pendimethalin은 76.9, 및 fipronil은 71.6로서 70 80\%의 회수율을 나 타내었고 alachlor은 66.8 및 dichlofluanid은 64.5였으며, trifluralin은 $37.5 \%$ 로서 매우 낮았다. 대파의 경우에는 G1 그룹 농약 중에서 trifluralin이 $79.8 \%$ 로서 회수율이 가장 낮았다. 쪽파는 trifluralin이 $75.9 \%$ 와 buprofezin이 $73.2 \%$ 를 나타내었 고 나머지 15 종의 성분은 $80 \%$ 이상의 회수율을 나타내었다. $\mathrm{G} 2$ 그룹 13성분 농약의 회수율(Table 3)은 양파의 경우 모두 $80 \%$ 이상을 타나내었으며, 대파와 쪽파는 thenylchlor이 각각 $79.4 \%$ 와 $75.1 \%$ 로서 다소 낮았다. G3 그룹 11 성분의 농약 회수 율(Table 4)은 양파의 경우 vinclozolin이 $78.2 \%$ 와 tolylfluanid 이 $73.3 \%$ 로서 $70 \sim 80 \%$ 범위이었으며, ethalfluralin은 $37.4 \%$ 로 서 매우 낮았다. 대파의 경우에는 metolachlor이 $75.6 \%$ 와 ethalfluralin이 $64.8 \%$ 로서 아주 낮았다. 쪽파의 경우에는 metolachlor는 $71.6 \%$ 와 ethalfluralin은 $60.1 \%$ 로 매우 낮았다. 세 계 각국 또는 국제기구 등에서 분석방법의 적합성 여부를 판 단하기 위하여 해당 분석법의 회수율 및 변이계수 등의 범위 를 설정하여 운영하고 있는데 그 적정범위는 나라 또는 기관 마다 조금씩 다르다. 유럽연합(EU)의 경우 회수율과 정밀도

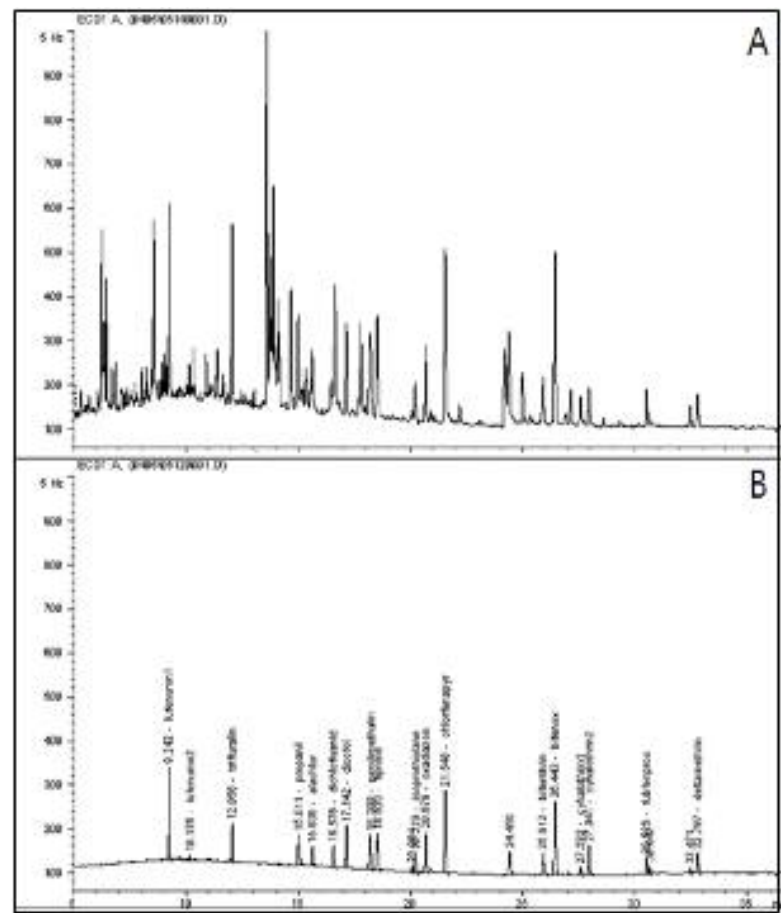

Fig. 4. Comparison of the chromatogram (A) composed of complex peaks of sulfur compounds and pesticides (group 1) from onion extract after clean-up by raw Florosil cartridge and that (B) composed of simple peaks of pesticides (group 1) after silver ion impregnated Florosil cartridge; $9.242 \mathrm{~min}$. as retention time: Lufenuron 1, 10.175: Lufenuron 2, 12.056: Trifluralin, 15.011: Propanil, 15.636: Alachlor, 16.576: Dichlofluanid, 17.142: Dicofol, 18.200: Pendimethalin, 18.520: Piperonil, 20.229: Isoprothiolane, 20.679: Oxadiazon, 21.548: Chlorfenapyr, 25.912: Bifenthrin, 26.443: Bifenox, 27.582: Cyhalothrin 1, 27.941: Cyhalothrin 2, 30.526: Fubfenprox, 32.797: Deltamethrin.

권장기준인 변이계수(coefficient of variation, $\mathrm{CV}$ ) 값이 각각 $70 \sim 110 \%$ 와 $20 \%$ 이내, $\mathrm{FAO}$ 는 $70 \sim 120 \%$ 와 $20 \%$ 이내, 미국 $\mathrm{FDA}$ 는 회수율 값을 $80 \sim 110 \%$ 로 운영하고 있다[6,7,21]. 본 연 구에서 파속류에 대한 농약 40 종의 회수율은 농산물의 종과 농약의 종류에 따라서 달랐다(Table 2 4). 17종의 G1 그룹 농약 회수율은(Table 2) 양파의 경우 80 110\%가 11종, 70 $80 \%$ 가 3 종, $70 \%$ 이하가 3 종이었으며, 대파의 경우에는 80 $110 \%$ 가 16 종 및 $70 \sim 80 \%$ 가 1종이었으며, 쪽파의 경우에는 $80 \%$ 이하가 2종이었다. G2 그룹 13성분 농약의 회수율(Table 3)은 대파와 쪽파가 각각 $79.4 \%$ 와 $75.1 \%$ 로서 $80 \%$ 보다 낮았 다. G3 그룹 11성분의 농약 회수율(Table 4)은 양파의 경우 2종이 70 80\% 사이었으나 1종은 $37.4 \%$ 로서 매우 낮았으며, 대파와 쪽파의 경우에는 1 종이 $70 ~ 80 \%$ 와 1종은 $70 \%$ 이하였 다. 이러한 결과는 유럽연합 및 $\mathrm{FAO}$ 기준에 부합되는 적정범 위 내의 회수율에 포함되는 농약에 대해서는 효율적인 분석법 이라고 판단하였다. 
Table 2. Recoveries of group 1 pesticides on silver ion impregnated Florosil cartridge (\%)

\begin{tabular}{lrrrrrr}
\hline \multirow{2}{*}{ Pesticides } & \multicolumn{2}{c}{ Onion } & \multicolumn{2}{c}{ Spring onion } & \multicolumn{2}{c}{ Shallot } \\
\cline { 2 - 7 } & Mean $\begin{array}{c}\text { Standard } \\
\text { deviation }\end{array}$ & Mean & $\begin{array}{c}\text { Standard } \\
\text { deviation }\end{array}$ & Mean & $\begin{array}{c}\text { Standard } \\
\text { deviation }\end{array}$ \\
\hline Lufenuron & 80.2 & 6.3 & 81.1 & 5.7 & 84.9 & 11.4 \\
Trifluralin & 37.5 & 2.6 & 79.8 & 3.2 & 75.7 & 5.7 \\
Propanil & 82.9 & 6.7 & 106.2 & 3.1 & 99.9 & 1.0 \\
Alachlor & 66.8 & 5.4 & 103.4 & 2.0 & 94.8 & 3.9 \\
Dichlofluanid & 64.5 & 6.9 & 112.0 & 0.4 & 114.1 & 7.9 \\
Dicofol & 74.9 & 5.2 & 88.7 & 0.6 & 90.6 & 2.4 \\
Pendimethalin & 76.9 & 4.2 & 94.9 & 2.3 & 92.4 & 1.9 \\
Fipronil & 71.6 & 11.6 & 102.8 & 2.4 & 84.8 & 9.6 \\
Isoprothiolane & 85.0 & 6.6 & 106.3 & 5.5 & 101.9 & 4.8 \\
Oxadiazon & 86.7 & 3.2 & 97.0 & 0.2 & 95.3 & 1.9 \\
Buprofezin & 53.3 & 20.7 & 85.0 & 2.2 & 73.2 & 13.0 \\
Chlorfenapyr & 86.7 & 5.6 & 100.8 & 0.4 & 100.0 & 1.8 \\
Bifenthrin & 88.5 & 4.5 & 100.9 & 0.4 & 99.8 & 2.1 \\
Bifenox & 94.0 & 4.3 & 103.9 & 3.0 & 103.4 & 2.6 \\
Cyhalothrin & 91.7 & 9.8 & 108.6 & 1.1 & 106.7 & 2.4 \\
Fubfenprox & 92.2 & 16.7 & 111.6 & 2.5 & 114.6 & 10.7 \\
Deltamethrin & 103.3 & 10.3 & 126.1 & 2.6 & 127.3 & 9.1 \\
\hline
\end{tabular}

Table 3. Recoveries of group 2 pesticides on silver ion impregnated Florosil cartridge (\%)

\begin{tabular}{lrrrrrr}
\hline \multirow{2}{*}{ Pesticides } & \multicolumn{2}{c}{ Onion } & \multicolumn{2}{c}{ Spring onion } & \multicolumn{2}{c}{ Scallion } \\
\cline { 2 - 7 } & Mean $\begin{array}{c}\text { Standard } \\
\text { deviation }\end{array}$ & Mean & $\begin{array}{c}\text { Standard } \\
\text { deviation }\end{array}$ & Mean & $\begin{array}{c}\text { Standard } \\
\text { deviation }\end{array}$ \\
\hline Flufenoxuron & 97.1 & 2.0 & 96.4 & 0.8 & 100.4 & 12.4 \\
Chlorfluazuron & 91.4 & 1.1 & 98.4 & 3.2 & 90.5 & 9.5 \\
Folpet & 89.6 & 3.4 & 116.2 & 3.8 & 116.4 & 19.3 \\
Oxyfluorfen & 95.6 & 1.1 & 94.6 & 1.7 & 96.8 & 1.6 \\
Thenylchlor & 96.8 & 5.7 & 79.4 & 1.3 & 75.1 & 7.1 \\
Fenpropathrin & 98.4 & 0.5 & 96.6 & 2.8 & 98.6 & 0.9 \\
Tetradifon & 96.1 & 1.9 & 93.9 & 1.8 & 95.2 & 2.7 \\
Acrinathrin & 91.6 & 0.3 & 91.5 & 3.0 & 94.5 & 2.1 \\
Pyridaben & 98.2 & 2.9 & 90.4 & 4.4 & 92.4 & 1.1 \\
Flucythrinate & 106.2 & 0.4 & 111.8 & 5.2 & 115.0 & 4.3 \\
Fenvalerate & 108.9 & 1.9 & 115.9 & 4.4 & 121.9 & 3.6 \\
Tralomethrin & 102.9 & 2.0 & 103.1 & 4.1 & 110.5 & 13.9
\end{tabular}

Table 4. Recoveries of group 3 pesticides on silver ion impregnated Florosil cartridge (\%)

\begin{tabular}{lrrrrrr}
\hline \multirow{2}{*}{ Pesticides } & \multicolumn{2}{c}{ Onion } & \multicolumn{3}{c}{ Spring onion } & \multicolumn{2}{c}{ Shallot } \\
\cline { 2 - 7 } & \multicolumn{3}{c}{$\begin{array}{c}\text { Standard } \\
\text { deviation }\end{array}$} & $\begin{array}{c}\text { Mean } \\
\text { Standard } \\
\text { deviation }\end{array}$ & Mean & $\begin{array}{c}\text { Standard } \\
\text { deviation }\end{array}$ \\
\hline Ethalfluralin & 37.4 & 4.2 & 64.8 & 5.9 & 60.1 & 5.5 \\
Chlorothalonil & 67.1 & 3.3 & 99.1 & 8.3 & 95.6 & 3.5 \\
Vinclozolin & 78.2 & 3.1 & 88.0 & 2.6 & 86.3 & 1.3 \\
Metolachlor & 82.0 & 3.8 & 75.6 & 1.4 & 71.6 & 3.3 \\
Tolylfluanid & 73.3 & 3.5 & 88.9 & 6.9 & 84.1 & 2.2 \\
Procymidone & 91.0 & 1.8 & 82.9 & 14.1 & 81.5 & 13.9 \\
Endosulfan & 88.0 & 2.7 & 93.1 & 4.0 & 90.7 & 3.7 \\
Kresoxim-methyl & 94.9 & 1.9 & 95.1 & 2.8 & 92.0 & 1.4 \\
Iprodione & 101.4 & 1.1 & 130.6 & 12.0 & 126.6 & 9.4 \\
Cyfluthrin & 98.4 & 3.6 & 107.8 & 13.2 & 112.7 & 5.0 \\
Cypermethrin & 97.3 & 3.3 & 111.2 & 4.7 & 114.6 & 9.3 \\
\hline
\end{tabular}

감사의 글

이 논문은 부산대학교 자유과제 학술연구비(2년)에 의하여 연구되었음.

\section{References}

1. Ahmed, F. E. 2001. Analysis of pesticides and their metabolites in foods and drinks. Trends Anal. Chem 20, 649-661.

2. Balinova, A. 1998. Multiresidue determination of pesticide in plants by high-performance liquid chromatography following gel permeation chromatographic clean-up. J. Chrom $823,11-16$.

3. Bennett, B. and S. R. Larter. 2000. Quantitative separation of aliphatic and aromatic hydrocarbons using silver ion-silica solid phase extraction. Anal. Chem 72, 1039-1044.

4. Block, E. 1992. The organosulfur chemistry of the genus Allium-Implications for the organic chemistry of sulfur. Angew. Chem 31, 1135-1178.

5. Chen, S., X. Yu, X. He, D. Xie, Y. Fan, and J. Peng. 2009. Simplified pesticide multiresidues analysis in fish by low-temperature cleanup and solid-phase extraction coupled with gas chromatography/mass spectrometry. Food Chem 113, 1297-1300.

6. FAO, Joint $\mathrm{FAO} / \mathrm{WHO}$ food standards programme. 2000. Codex Alimentarius commission, pesticide residues in food-methods of analysis and sampling, 2A(1), 39-47.

7. FDA. 1999. Multiresidue Method, pp. 51-69, Pesticide Anal. Manual. Vol. 1.

8. Fernandez, M., Y. Pico, and J. Manes. 2002. Analytical methods for pesticideresidue determination in bee products. $J$. Food Prot. 65, 1502-1511.

9. Gundermann, K. D., H. P. Ansteeg, and A. Glitsch. 1983. Ligand exchange chromatography of coal extracts and coal products. Proc. Intern. Confer. on Coal Sci. Pitsburgh, 631-640.

10. Kang, C. S., D. W. Choi, G. S. Oh, S. K. Park, J. D. Choi, J. S. Jin, S. H. Choi, J. H. Lee, M. J. Kim, and I. S. Song. 2004. Optimization of multiclass multiresidue pesticides for analytical methods in foods. The Ann. Report of KFDA 8, 405-420.

11. Karazafiris, E., U. Menkissoglu-Spiroudi, and A. Thrasyvoulou. 2008. New multiresidue method using solid-phase extraction and gas chromatography-micro-electron-capture detection for pesticide residues analysis in royal jelly. J. Chrom A 1209, 17-21.

12. Kim, K. D. and Y. C. Seo. 2009. Evaluation of organochlorine pesticides extraction efficiency by ASE pretreatment. J. Korean Soc. Environ. Anal. 12, 144-149.

13. Kim, T. J., Y. W. Eo, and Y. S. Kim. 1986. Studies on simultaneous analysis of organophosphorous pesticide residues in crops by gas-liquid chromatography (1) Extraction and cleanup. J. Korean Chem Soc. 30, 465-474.

14. Kristenson, E. M., L. Ramos, and U. A. T. Brinkman. 2006. Recent advances in matrix solid-phase dispersion. Trends 
Anal. Chem 25, 96-111.

15. Lanzotti, V. 2006. The analysis of onion and garlic. J. Chrom A, 1112, 3-22.

16. Lilia, L., M. Lagunas, and F. Castaigne. 2008. Effect of temperature cycling on allinase activity in garlic. Food Chem $111,56-60$.

17. Michael, G., H. Al-Rabiah, R. Kadmi, and M. Al-Mojbet. 2007. Separation of sulfur compounds from a diesel fraction by ligand exchange chromatography. J. Liquid Chrom \& Related Technol. 30, 1577-1601.

18. Miron, T., I. Shin, G. Feigenblat, L. Weiner, D. Mirelman, M. Wilchek, and A. Rabinkov. 2002. A spectrophotometric assay for allicin, alliin, and allinase (alliin lyase) with a chromogenic thiol: reaction of 4-mercaptopyridine with thiosulfinates. Anal. Biochem 307, 76-83.

19. Park, J. J., K. C. Yong, and J. A. Jeung. 2000. An extraction method and residues of benzimidazole fungicides in soybean sprouts. Korean J. Pesticide Sci. 4, 26-31.

20. Pereira, L. A. and S. Rath. 2009. Molecularly imprinted solid-phase extraction for the determination of fenitrothion in tomatoes. Anal. \& Bioanal. Chem 393, 1063-1072.

21. Philip, W. L. 2003. Handbook of residue analytical methods for agrochemicals. 13-17.

22. Pico, Y., G. Font, J. C. Molto, and J. Manes. 2000. Pesticide residue determination in fruit and vegetables by liquid chromatography-mass spectrometry. J. Chrom A 882, 153-173.
23. Picó, Y., M. Fernández, M. J. Ruiz, and G. Font. 2007. Current trends in solid-phase-based extraction techniques for the determination of pesticides in food and environment. J. Biochem Biophys. Meth 70, 117-131.

24. Pico, Y., R. Rodriguez, and J. Manez. 2003. Capillary electrophoresis for the determination of pesticide residues. Trends Anal. Chem 22, 133-151.

25. Seo, Y. C., M. K. Heo, S. Y. Kim, J. E. Shin, Y. H. Park, and K. D. Kim. 2008. Efficiency evaluation of organophosphorus pesticides analysis by ASE pre-treatment technique and its application to vegetable samples. J. Korean $S o$. Environ. Anal. 11, 1-5.

26. Torres, C. M., Y. Pico, and J. Manes. 1996. Determination of pesticide residues in fruit and vegetables. J. Chrom $A$ 754, 301-331.

27. Tu, O. J., B. K. Jung, G. S. Kim, E. G. Jeong, J. G. Kim, and M. H. Kim. 2002. Efficiency of eluting solvents for solid-phase extraction during multiresidue analysis of 16 pesticides in cucumber. Korean J. Environ. Agric. 21, 90-95.

28. Vough, J. W. and J. E. Dooley. 1975. Separation of organic sulfides from aromatic concentrates by ligand exchange chromatography. Anal. Chem 47, 816-821.

29. Wang, H., j. Li, Z. Wang, X. Zhang, and Y. Ni. 2007. Modified method for rapid quantitation of $S$-alk(en)yl-Lcysteine sulfoxide in yellow onions (Allium cepa L.). J. Agric. Food Chem 55, 5429-5435.

\section{초록 : 파속류의 잔류농약분석과정에서 silver ion-silica solid phase extraction에 의한 황화합물의 제거 효율성 \\ 박진우 $\cdot$ 문경미 ${ }^{1} \cdot$ 최영환 ${ }^{2} \star \cdot$ 이영근 $^{3}$ \\ (인천지방조달청, ${ }^{1}$ 국립농산물품질관리원 경남지원, ${ }^{2}$ 부산대학교 원예생명과학과, ${ }^{3}$ 부산대학교 식품공학과)}

파속류에 다량 함유된 황화합물들은 $\mathrm{GC} / \mathrm{ECD}$ 에 민감하게 반응하기에, 이 농산물들의 잔류농약분석에서 방해 물질로 작용하여 농약성분의 분리정량에 어려움을 주고 있다. 최근 잔류농약분석에서 정제법으로 여러 가지 고상 추출법(solid-phase extraction)이 개발되고 있으며, 본 연구에서는 황화합물을 효율적으로 제거하기 위하여, $20 \%$ 질산은 $\left(\mathrm{AgNO}_{3}\right)$ 용액 $3 \mathrm{ml}$ 을 Florosil cartridge $(1 \mathrm{~g}$ packing, $6 \mathrm{ml}$ tube)에 처리한 은이온흡착 cartridge (silver nitrate impregnated florosil cartridge)를 조제하였다. 이 cartridge를 이용하여 파속류 각 2, 4, 6 및 $10 \mathrm{~g}$ 에 해당하 는 추출액을 고상추출법으로 정제한 결과, 양파 $6 \mathrm{~g}$, 대파 $4 \mathrm{~g}$, 쪽파는 $4 \mathrm{~g}$ 까지는 황화합물의 $95 \%$ 이상을 제거할 수 있었다. 그리고, 40 종의 농약을 각 파속류에 첨가하고 이 cartridge에서 유출하여 회수율을 분석한 결과 34 종이 $70 \sim 120 \%$ 의 범위 안에 들었다. 